\title{
Integrating Africa: Some Trade Policy Research Priorities and Challenges $\#$
}

\author{
Bernard Hoekman $^{\mathrm{a},{ }^{*}}$ and Dominique Njinkeu ${ }^{\mathrm{b}}$
}

${ }^{a}$ Robert Schuman Centre for Advanced Studies, EUI and CEPR. ${ }^{\mathrm{b}}$ African Trade and Sustainable Development (AFTSD) and Senior Programme Associate, Global Governance Programme, EUI

*Corresponding author: Bernard.Hoekman@EUI.eu

\begin{abstract}
This paper discusses opportunities for trade policy research to contribute more to efforts to integrate African markets, a stated policy priority for African leaders. Much of the economic research in this area has sought to quantify aggregate trade costs and the potential welfare impacts of reducing such costs, including through regional integration. This is important, but we argue that more focus is needed on the 'micro' dimensions of regional integration. These center on the trade-restricting effects of nontariff measures and regulatory policies and their political economy underpinnings. Of particular importance is research on mechanisms to support market integration initiatives that recognize the multidimensional nature of the sources of trade costs in Africa, and the associated political economy forces within and between countries and regional economic communities.
\end{abstract}

Keywords: trade costs; nontariff measures, trade facilitation; regional integration; services markets

JEL codes: F13, F15, O19, O55

${ }^{\#}$ An initial draft of this paper was presented at the African Economic Research Consortium (AERC) research workshop on 'Integrating African Markets: The Way Forward', May 29-June 2, 2016 Nairobi, Kenya. We are grateful to Sekou Falil Doumbouy, Leonce Ndikumana, Witness Simbanegavi and two referees for helpful comments and suggestions. The authors are grateful to the African Economic Research Consortium for providing financial support for the preparation and presentation of this paper at the June 2016 AERC Biannual Research Workshop. 


\section{Introduction}

Much has changed in the geographic pattern of Africa's trade in recent decades. The EU as a bloc remains the continent's largest trade partner, but China and India have become the top two individual trading partner countries for Africa as a whole (African Economic Outlook, 2017). There has been a gradual expansion in the share of non-fuel merchandise in total exports, reflecting increases in exports of manufactured and agricultural products as well as trade in services, in turn reflecting gradual progress in structural transformation (McMillan and Harttgen, 2014). ${ }^{1}$ However, much also remains the same. Many countries remain heavily dependent on a limited number of products for their foreign exchange revenues. Intra-regional trade, despite rising steadily since 2008 , stands at 18 percent of total, well below that observed in most other parts of the world. Although the intra-Africa share is higher for trade in agricultural products (27 percent), ${ }^{2}$ the manufacturing share is only 15 percent (WTO, 2016). The potential for increasing intra-African regional trade remains significant. ${ }^{3}$ An important change in recent years is that this potential is now being pursued with greater seriousness by African leaders and, critically, the private sector (Brenton and Hoffman, 2016).

Trade and investment policy reforms, in part undertaken to integrate subsets of African markets, have led to a steady reduction in trade barriers. Trade policy has changed substantially compared to the situation described in surveys published in the late 1990s and early 2000s (Rodrik, 1998; Lyakurwa et al. 1997; Oyejide et al. 1999; Ackah and Morrissey, 2005). Many African economies are relatively open to trade in goods and services, although the average most-favored-nation (MFN) tariff remains higher than in many other regions and a number of countries use import and/or export bans for sensitive products. Simple average MFN tariffs are in the 12 to 18 percent range for many subSaharan African nations/regional economic communities (RECS), with average rates of protection for agricultural products exceeding rates for nonagricultural goods by between 30 and 100 percent. ${ }^{4}$ Although higher tariffs often protect specific domestic industries, a feature of the tariff schedules of most African countries is that there are relatively few tariff peaks-tariffs that are more than three times higher than the average rate. ${ }^{5}$ The stylized fact that African borders are "thick" remains salient, however (Brenton and Isik, 2012), reflecting both tariffs and nontariff barriers. Thus, from a policy perspective the regional integration agenda revolves around removing the MFN tariffs that apply to inter-bloc trade and reducing the trade-restricting effects of (differences in) regulatory policies affecting the cross-border movement of goods, services, capital (investment; knowledge) and people - "nontariff measures" (NTMs).

The African Union's Agenda 2063 provides a vision for "the Africa we want" (African Union Commission, 2015): "an integrated, prosperous and peaceful Africa, driven by its own citizens and representing a dynamic force in the global arena." ${ }^{6}$ It is a blueprint for a prosperous Africa, based on inclusive growth and sustainable development, with structural transformation creating shared growth, decent

\footnotetext{
${ }^{1}$ This trend accelerated as a result of the steep fall in the world oil price in mid-2014, with prices staying low through the time of writing in mid-2017 and not expected to increase in the near future.

${ }^{2}$ See Cissokho et al. (2013) for an analysis why this is the case in West Africa.

${ }^{3}$ See, e.g., de Melo and Tsikata (2015) or Geda and Kibret (2008). It is well known that official trade statistics understate actual intra-African trade by not capturing informal trade and, in some instances, smuggling.

${ }^{4}$ Tariff data are from WTO, ITC and UNCTAD (2017).

${ }^{5}$ The South African Customs Union is an exception in this regard, with 9.5 percent of tariff lines incurring tariffs that are more than three times the average of 7.7 percent. However, the average SACU tariff rate is less than that applying in other RECs in Africa.

${ }^{6}$ African Union website at: https://au.int/en/about/vision.
} 
jobs and economic opportunities for all. The agenda envisages a continent where there is free movement of people, capital, goods and services and a substantial increase in trade and investment among African countries. The "apex" institutional framework to support this is the Continental Free Trade Area (CFTA), supported by an African Union initiative 'Boosting Intra-Africa Trade' (BIAT). The latter defines seven priority areas for action: trade facilitation, trade policy, productive capacities, trade related infrastructure, trade finance, trade information and factor market integration. ${ }^{7}$

Many of these areas are important independent of regional integration efforts and do not require that they be pursued under the umbrella of the extant RECs or the CFTA. Variable geometry-based projects and programs among subsets of countries belonging to one or multiple RECs may be more effective and appropriate in terms on internalizing incentives for international cooperation, in areas such as joint infrastructure, for example. One challenge for policymakers is to determine the value added of pursuing cooperation under the umbrella of regional integration agreements as opposed to unilateral reforms and engaging plurilaterally on an issue-specific basis, a question on which there has been relatively little research in an African context. ${ }^{8}$

Integrating Africa will require both deepening and rationalization of disparate regional integration processes. A step in this direction has been taken with the agreement to consolidate the East African Community (EAC), the Common Market for Eastern and Southern Africa (COMESA) and the Southern Africa Development Community (SADC) into the Tri-Partite Free Trade Area (TFTA), which was launched in 2015. In addition to pursuing the integration of African RECs, the regional integration agenda has an external dimension. African sub-regions have negotiated (or are in the process of negotiating) Economic Partnership Agreements (EPAs) with the European Union (EU) - these may need to be revisited as Africa integrates. African LDCs have duty-free, quota free access to many highincome markets that imply different members of the CFTA will have diverse external market access conditions, requiring firms to comply with different sets of rules of origin. ${ }^{9}$

Realizing the ambitious intra-regional trade agenda is a multidimensional challenge that confronts several key attributes of African trade policymaking, including:

- Political economy forces opposing trade liberalization: while the marginal tariff reductions associated with deepening preferential trade agreements (PTAs) are not very large in most cases, there will be adjustment costs for industries benefitting from above average MFN tariffs that, unless properly managed, may induce successful lobbying that prevent African countries from fully taking advantage of new market opportunities.

- Inter-REC liberalization: over the last three decades autonomous liberalization at the national levels or within RECs has led to less attention for liberalizing across regions. As a

\footnotetext{
${ }^{7}$ The AU, AfDB and UNECA (2016) develops and reports an index monitoring progress in achieving regional integration objectives for the eight main RECs in Africa. Noteworthy however is that the index does not cover NTMs or services trade barriers - in our view, as discussed in what follows, key dimensions of effectively integrating Africa. See Afesorgbor (2017) for a recent meta-analysis of the empirical literature estimating the effects of African RECs in fostering intra-regional trade.

${ }^{8}$ As noted by de Melo and Tsikata (2015), the pursuit of the linear model of regional integration (from free trade areas to customs unions and common markets to economic and monetary union) historically has been a brake on implementation of needed policy reforms, including many that should have been pursued autonomously. See also Karingi and Davis (2016).

${ }^{9}$ See e.g., Frazer and van Biesebroeck (2010) and Persson and Wilhelmsson (2013) on US and EU preference programs, and Cadot et al. (2006), Bombarda and Gamberoni (2013), Conconi et al. (2016) and Estevadeordal and Suominen (2008) on the rules of origin that accompany trade preferences.
} 
result, exports between two African countries that are in different RECs often face the highest tariffs. Likewise, NTBs are also highest for neighboring countries that are not members of the same REC.

- Lack of capacity of stakeholders to generate/use, screen and validate research and associated recommendations to properly inform policy making;

- Inadequate attention for the macro-economic dimensions of economic integration, such as ensuring that the real exchange rate is not over-valued;

- Weak and/or inappropriate governance and regulatory frameworks for nurturing the nexus between trade, economic growth and development;

- Limited efforts by national and regional policy-research organizations, business groups and civil society organizations to work effectively together; and

- A multiplicity of trade capacity building programs that often are too much aligned with donor agency priorities, or programs that target specific and narrow aspects of the trade agenda.

The goal of this paper is to discuss several areas where research could have high payoffs in informing and supporting the integration process by addressing or encompassing some of these attributes. In doing so we adopt a trade costs lens and a focus on regulatory, 'behind-the-border' policies that impact on market integration. Specifically, we discuss four research challenges:

(i) Analysis of the effects of trade policy, especially NTMs affecting trade in goods and services. Here the research question is to identify what policies matter most for welfare, taking into account distributional dimensions, in particular the extent to which policies create rents for concentrated groups as opposed to policies that generate significant social waste (raise costs without generating rents or tax revenues) - which should be more straightforward to pursue. A challenge here is data - to characterize policies accurately and to quantify rents (distributional effects) - which calls for a mix of standard data collection methods and working with stakeholders and private sector groups that stand to gain from market integrating reforms to generate data.

(ii) Research on issues related to inter-REC liberalization. In part, the research agenda here is well understood, centering on modalities for intra-African removal of tariffs and considering the associated political economy dynamics. But intra-REC tariff removal requires agreement on rules of origin, a subject that has not attracted much Africa-specific research. Other areas for research concern cooperation to reduce the trade-impeding effects of NTMs and modalities to liberalize services markets and the movement of services providers (people).

(iii) Improving economic governance and regulatory frameworks. A large body of research has documented the importance of good governance for economic development-political stability, rule of law, control of corruption. Such factors impact on the gains from liberalization and their absence may reduce net gains significantly (Nunn and Trefler, 2015; Rodriguez and Rodrik, 2001). Market integration can be an instrument to improve economic governance at the sector-specific or economy-wide level through agreement on enforceable rules of the game or the creation of common institutions. A research question here is to determine where rules/cooperation could have significant payoffs in the African context and how this 
could be structured. This is a relatively neglected subject in the literature on African regional integration, although not of course in the economic development literature-creating opportunities for cross-fertilization.

(iv) The design of mechanisms to enhance policy coherence and accountability. A large number of policies are relevant in efforts to integrate markets, many of which may not be covered by regional trade arrangements. Areas and initiatives that are included under the umbrella of regional integration will affect many stakeholders. Leveraging their knowledge and involving them in the process of implementation can help increase the prospects for integrating Africa by generating relevant, timely feedback on progress, or lack thereof, and increase accountability for results. A research question here concerns the design of monitoring mechanisms to enhance transparency and information on implementation and for firms and other stakeholders to be able to raise non-implementation of agreements before independent review bodies. These are matters on which economic research can contribute, as it raises issues of incentive compatibility, information revelation, and governance (e.g., to prevent capture by vested interests), but where there is a need for multidisciplinary collaboration with legal scholars and political scientists.

These are only a subset of research questions that are relevant to regional integration. They are more of an "operational" nature than the questions that tend to motivate economic research on regional integration, which usually focus on issues such as measurement of trade and welfare effects, (potential) magnitudes of trade diversion and trade creation, and the role of geography and hard infrastructure as a factor reducing (formal) trade far below potential. ${ }^{10}$ We focus instead on topics that pertain more to the realization and implementation of regional integration initiatives, that are researchable and where there are clear gaps between what has been done to date and what is needed. They are all inter-related - all have a political economy dimension and bear on the design of regional integration processes.

Other subjects are of course very salient as well, such as real exchange rate management; measuring the externalities associated with national subsidy and industrial policies; and the external policy dimensions of African integration - e.g., what can and should be done through the WTO; with nonAfrican partners. These questions are all important but are either well understood (e.g., issues associated with macroeconomic policy and the real exchange rate-e.g., Rodrik, 2008; Freund and Pierola, 2008); unlikely to be addressed in a CFTA; or endogenous to progress in integrating Africa. For example, insofar as the latter is successful and gives rise to trade diversion costs this will create incentives for trading partners to negotiate with African countries and blocs, including in the WTO.

The plan of the paper is as follows. We start in Section 1 with a discussion of recent research on trade costs which has helped to mobilize a broad effort across Africa to implement initiatives to facilitate trade in goods and to re-energize political attention for regional integration. This is used as a framework to identify different dimensions of integrating markets that have been relatively neglected in the research literature, including analysis of NTMs and issues around liberalization of trade and investment in services and the cross-border movement of service providers. These areas are all criti-

${ }^{10}$ See, e.g., Limão and Venables (2001) and Francois and Manchin (2013) on the latter, and Geda and Seid (2015) on the former type of analysis. De Melo and Tsikata (2015) is an excellent recent review of the economic literature on African regional integration. 
cal to integrating Africa. They are the subject of Sections 2 through 5, which discuss dimensions of the four research challenges mentioned previously. Section 6 concludes.

\section{Trade costs, trade policies and regulatory regimes}

Africa accounts for only 2 percent of global imports of intermediate products, parts and components (WTO, 2015), illustrating the very limited extent to which African countries participate in crossborder value chains. There are significant opportunities for a step increase in regional supply chain trade in Africa (UNECA, 2013; Pesce, Karingi and Gebretensaye, 2015; Morris and Fessehaie, 2015; Kaplinsky and Morris, 2015). A necessary condition for sustaining and increasing participation in cross-border value chains and attracting investment is lowering trade costs and reducing uncertainty for traders regarding market entry conditions. This is particularly important for small firms, as their lower scale of production implies higher unit trade costs, given the significant fixed component of dealing with administrative requirements at the border, unpredictable variable costs generated by delays, and the differences in regulations across markets (e.g., Christ and Ferrantino, 2011; Hillberry and Zhang, 2015).

The empirical economic literature has used indicators of trade costs from the World Bank's Doing Business database (the "trading across borders" variable in particular) and firm-level survey information to quantify the effects of trade and related transactions costs. A representative example is Djankov, Freund and Pham (2010), who use export time as reported in the database as an indicator of national trade facilitation performance. This measure includes the time needed for document preparation, internal transport, passage through customs and other border agencies, and port and terminal handling. They find that the time to export measure is a statistically significant determinant of bilateral trade flows, with each day's delay associated with a reduction in bilateral trade of at least one percent. In the case of Africa, Freund and Rocha (2011) estimate it is 1.5 percent. Beverelli et al. (2015) conclude that measures to facilitate trade will have significant positive impacts on diversification along the extensive margin for African countries. They estimate that full implementation of the various measures that are called for in the WTO Trade Facilitation Agreement (TFA) could support an increase of some 16 percent in the number of products exported by sub-Saharan African countries and an increase of up to 14 percent in the number of export destinations by product. ${ }^{11}$

Such 'macro' research has helped to raise awareness of the importance of action to reduce trade costs, but is not necessarily very useful in identifying where regional integration efforts should focus. For this, policymakers need more specific guidance. Regional integration is an instrument to reduce trade costs through a mix of market access liberalization - removing tariffs and NTBs - and facilitation: measures to ease cross-border movement of products, producers and people. Trade costs are in part a function of factors that cannot be changed such as geography, but to a significant extent they reflect policy variables: the tariff and other trade policies of a country, those of trading partners, investment in transport infrastructure, encouraging competitive logistics services and the quality of economic governance.

Many of these are NTMs that establish the conditions of competition, including regulatory policies pertaining to product quality, health and safety standards for goods and services. Cadot and Gourdon (2014), for example, estimate that sanitary and phytosanitary (SPS) measures increase av-

\footnotetext{
${ }^{11}$ See, also, e.g., Hoekman and Nicita (2011), Persson (2013), Spence and Karingi (2011), and Saslavsky and Shepherd (2014).
} 
erage prices in African countries by some 14 percent, which is similar in magnitude to the average import tariff for agricultural goods (WTO et al. 2017). Services trade liberalization also centers on NTMs. Services trade costs are higher than for goods in part because trade often requires movement of providers (people) and/or foreign direct investment (FDI).

\section{Discriminatory vs. nondiscriminatory NTMs}

NTMs may comprise (i) regulatory policies that apply to all firms, both national and foreign; and (ii) policies that are designed to discriminate against foreign providers or consumption abroad. This distinction is salient for both trade in goods and trade in services. This distinction is often ignored in empirical work - much of the trade restricting effect of policies characterized as NTBs (i.e., as discriminatory) may in fact be picking up the effect of nondiscriminatory NTMs. Cadot and Gourdon (2016) estimate average ad-valorem tariff equivalents (AVEs) for SPS measures, technical product standards and other NTMs using updated policy information compiled by UNCTAD and unit value trade data. They use these data to estimate price-gaps that can be attributed to NTMs. They find these to be in the single digits, substantially lower than estimates based on older data. Of particular salience for the subject of this paper is that they find that PTAs that include mutual recognition of conformity-assessment procedures substantially reduce the price-raising effect of (nondiscriminatory) NTMs.

Regulatory policies vary across countries for any given sector and the resulting heterogeneity is one source of international trade costs (OECD, 2017; Nordås, 2016). The problem for firms is that they must address a set of idiosyncratic regulatory requirements in each market they wish to contest. The effect of this heterogeneity is to increase the costs of contesting international markets and inhibit realization of economies of scale. There are several dimensions relevant here: (i) (asymmetric) information on the applicable regulations and administrative requirements; (ii) associated national certification/conformity assessment processes; and (iii) uncertainty/variability in administration of (i) and (ii). These factors generate trade costs even if regulation is non-discriminatory.

For empirical work assessing the effects of trade costs or the impacts of specific policies such as standards, whether measures are discriminatory does not matter. Trade costs estimates center on the magnitude of the price wedge (estimated AVEs) of all policies and are less concerned with "unpacking" different sources of trade costs. However, to inform regional integration processes it is necessary to consider (analyze) different types of NTMs and distinguish between the effects of discriminatory as opposed to nondiscriminatory trade cost-creating measures. This is important as the solution to the trade cost increasing effects of these measures will differ - one can be addressed by eliminating the discriminatory policy, whereas the other calls for more complex forms of cooperation. Another challenge is to distinguish between measures that (mostly) generate social waste from those that do not, and for the latter set, to identify if and to what extent they generate rents as this will impact on the political economy of reform.

\section{Political economy dimensions}

Tariffs, NTM reforms and trade facilitation give rise to somewhat different political economy dynamics and constraints. Trade facilitation takes as given prevailing regulatory policies and NTMs: the aim is to lower the cost of administration of extant NTMs. An implication is that while trade facilitation efforts will confront resistance from officials and vested interests that benefit from inefficient customs clearance procedures, the political economy is relatively straightforward as policies per se are 
not at issue. Because the focus is on administrative processes, gains of reform to a significant extent arise from reductions in social waste arising from redundant controls and requirements. Regional integration is a much more ambitious endeavor. It does not take policies as given - the aim is remove discriminatory barriers to trade (tariffs, NTBs) and to reduce the trade costs associated with enforcement of nondiscriminatory NTMs. Some NTMs generate concentrated rents by restricting competition. Others address market failures of different sorts. In the latter cases, the issue is to ensure that measures to reduce trade cost raising effects do not come at the expense of attaining underlying regulatory goals. Analysis that helps to identify what matters most - what could have the biggest positive economic impact on investment and employment - will need to drill down into these issues.

\section{Services}

A key feature of deeper forms of regional integration is liberalization of trade and investment in services. For any level of economic development, the role of services in the economy is today more important than in the past because of technological changes in information and communication and other industries. Many services are inputs into production. As a result, their cost and quality impact on economy-wide performance. Some 50 percent of global trade on a value-added basis comprises services, reflecting the role of services as inputs into traded products. This is also the case for Africa: forward linkages are important, with the value added generated by sectors such as transport, communications, business and professional services used as intermediate inputs into production of goods (and services) that are exported across a range of industries (Arnold et al. 2008; Balchin et al. 2016; Beverelli et al. 2017).

Trade and investment liberalization is a channel to increase access to such inputs and improve economic performance. Research has shown that FDI is particularly important in this regard (Francois and Hoekman, 2010). Borchert et al. (2017), for example, note that many landlocked African countries restrict trade in services that are particularly important for overall trade performance - e.g., on average air-transport policies are significantly more restrictive than in other countries, reducing connectivity with the rest of the world. The consequence is more concentrated market structures, higher prices and less access to transport services. They estimate that even moderate liberalization of air transportation services by landlocked Sub-Saharan countries could generate a 20 percent increase in the number of flights. Miroudot and Shepherd (2016) find that a 10 percent higher average level of services trade restrictiveness is associated with an increase in trade costs of around 3 percent (using trade costs data compiled by Arvis et al. 2016). The effect on trade in intermediate products is larger than for final products. Hoekman and Shepherd (2017) show that services trade restrictiveness indices (STRI) compiled by the World Bank (Borchert et al., 2014) are negatively associated with manufactured exports performance. A 10 percent increase in the average STRI is associated with a 5 percent decrease in bilateral trade in manufactured goods. Regional integration is a mechanism to foster liberalization of restrictive trade and investment policies. ${ }^{12}$

\footnotetext{
${ }^{12}$ Results for specific countries provide a sense of how variation in STRIs impacts on trade performance. Four EAC member countries have an average services trade restriction score that is 25 or higher. The most restrictive is Uganda (an index of 35), followed by Tanzania and Kenya (with indices averaging around 30). The Hoekman-Shepherd analysis suggests that if the EAC as a group reduced the average level of services trade restrictions to that in Ghana (the African country with the lowest services trade barriers, with an index of 18), merchandise exports of Kenya, Tanzania and Uganda would rise by some 20 percent.
} 


\section{Assessing priorities and potential effects of regional integration}

An important policy challenge calling for economic analysis is to consider the effects of a variety of NTM policy instruments to assess expected effects on real incomes (aggregate welfare) of alternative reform options. Different instruments will affect sectors and economic activities differentially, and collectively impact on the performance of the economy as a whole. The standard tool to address this complexity is computable general equilibrium (CGE) modeling. The use of such models has been a staple of analysis of PTAs for decades. Their ability to analyze the potential effects of economic integration initiatives and inform policymakers on the effects of different types of reforms has improved substantially over time, as have datasets on relevant policies.

A "market leader' in applying this type of analysis to African contexts is David Tarr and his coauthors. They have developed and applied CGE models incorporating household level data to allow assessment of the distributional effects of trade and investment policy reforms, and used surveys and expert inputs to fill information gaps on prevailing policy regimes. Jensen et al. (2010) focus on the effects of liberalizing trade in services using a 52-sector CGE model of the Tanzanian economy. Their model incorporates FDI in services and allows for endogenous productivity effects in both goods and services markets. Using the results of a survey on sectoral regulatory regimes in Tanzania to estimate AVEs of FDI barriers, Jensen et al. conclude Tanzania could benefit significantly from services reforms in banking, maritime and road transportation. Most of these potential gains are associated with liberalization of NTMs that (in principle) apply on a nondiscriminatory basis.

In a related paper, Balistreri, Jensen and Tarr (2015) develop a similar CGE model that incorporates monopolistic competition, FDI in services and endogenous productivity effects stemming from additional varieties. They specify probability distributions of all parameters and execute the model 30,000 times to generate probabilities of reform outcomes. They apply the model to Kenya and show that preferential liberalization commitments in services could be welfare reducing, with losses being more likely the greater the share of the rents generated by competition-restricting measures that accrue to Kenyan persons. A policy issue that arises here is the feasibility of liberalizing FDI in services on a preferential basis. Even if this is technically feasible, in practice, regional integration may facilitate entry by affiliates of multinational firms so that even if reforms are applied on a preferential basis, affiliates of non-PTA headquartered firms that have already established in a participating African country will benefit from deeper regional integration initiatives. Much therefore depends on the "rules of origin" that will be applied as well as the degree to which liberalization can be (is) pursued on a discriminatory basis.

The country-specific models used in these papers are a basis for other research analyzing the potential effects of regional integration in Africa. Balistreri, Tarr and Yonezawa (2015) focus on the impacts of integration between African RECs, again including barriers to FDI in services and dimensions of trade costs. They show that reducing trade costs and FDI barriers are the most important drivers of the potential gains from greater integration, although the effects of different policy reforms vary substantially across African countries. Balistreri et al. (forthcoming) use a CGE-microsimulation model to assess the distributional effects of the creation of the TFTA and conclude this will result in significant reductions in the poverty headcount and increase the incomes of the bottom forty percent of the population for all of the African RECs considered, including those not participating in the TFTA. 
They decompose trade costs into: (i) trade facilitation; (ii) non-tariff barriers; and (iii) the costs of business services and find that NTMs and a lack of trade facilitation are a much more substantial source of trade costs than tariffs. An interesting finding is that trade facilitation tends to increase the share of income captured by the poorest 40 percent of the population, while services reform decreases the share. Estimated gains vary considerably across countries and types of reforms, suggesting that countries have an interest in negotiating different reforms in different agreements. ${ }^{13} \mathrm{An}$ implication of this heterogeneity for the more detailed design of regional integration is to better understand and identify priority areas for action. The design of mechanisms to permit (and incentivize) the business community to provide information needed to do so is an area for research that potentially can have a high impact. We return to this below.

The empirical literature estimating the magnitude of the trade costs prevailing in African countries and regions, based on efforts to collect information on relevant NTMs - such as the World Bank's Doing Business and Services Trade Restrictiveness databases, with associated estimation of AVEs (e.g., Jafari and Tarr, 2017) - has increased awareness of the potential gains from lowering trade costs, including through deeper integration of markets. To a lesser extent the same is true of the gravity model-based empirical literature analyzing the impacts of African RECs on intra-regional trade. This literature has recently been surveyed and critiqued by Afesorgbor (2017), who undertakes a meta-analysis of this body of research and argues that most extant studies of African RECs do not correct for multilateral resistance and the prevalence of zero observations. Once this is done, trade effects are lower, bolstering the conventional view that regional integration initiatives have had limited effects in removing trade barriers and that much therefore remains to be done. ${ }^{14}$

Gravity-based empirical analysis is useful in assessing potential effects of regional integration and measures to reduce trade costs. Some of the relevant research using this approach were mentioned earlier in this Section. CGE analysis is more useful to assess sectoral effects and impacts on wages and prices and thus as a tool to inform the design of regional integration initiatives. The CGE-based studies that use detailed information on tariff schedules, NTMs for goods, services trade and investment barriers and regulatory regimes are the workhorses of analyses of the potential effects of regional integration and more generally efforts to reduce trade and investment barriers. Although both types of methodologies generate useful information for policymakers, they are relatively 'macro' in nature, notwithstanding the sectoral detail that is embodied in CGE models and the productspecific nature of trade cost estimations. Both types of approaches provide valuable guidance on the types of reforms that are likely to generate welfare gains, but they remain rather abstract tools that are difficult for policymakers and citizens more generally to understand. A downside of CGE-based analyses is that they may be misused by politicians (and analysts) to generate large (or small) headline numbers that are not (perceived to be) credible. At the end of the day realizing the potential gains of regional integration revolves around implementation, which in turn confronts political economy constraints and informational gaps. This is an area where we perceive substantial opportunities for influential policy-relevant research.

\section{Analyses of specific trade policies}

\footnotetext{
${ }^{13}$ Mold and Mukwaya (2016) also evaluate the economic impact of the TTFA, using the Global Trade Analysis Project (GTAP) CGE model and associated database, focusing on the effects of removal of tariffs.

${ }^{14}$ See also Brenton and Isik (2012), Geda and Seid (2015) and De Melo and Tsikata (2015).
} 
Beghin et al. (2015) make a compelling case for partial equilibrium-based analyses that consider prevailing market structures, political economy dynamics and distributional dimensions of different specific policies. Analysis of the political economy of trade policy, especially nontariff measures, requires first and foremost information: data that characterizes policies accurately enough to allow quantification of rents, if any, and their distributional effects. ${ }^{15}$ As discussed above, information on NTMs and regulatory regimes is often not available or is difficult to compare across countries and time. International organizations have made efforts to compile such data, but the state of play in Africa leaves much to be desired. It is difficult for individual researchers to collect the requisite data on their own, helping to explain why analysis that engages with the political economy of regional integration in Africa is sparse. However, matters on the data front have been improving. The WTO makes available detailed data on applied MFN tariffs; the World Bank has compiled services trade restrictiveness indicators for many African economies and is working with the WTO to replicate this exercise and generate a panel dataset with a time dimension. The World Bank also compiles data on logistics performance (the LPI) and a variety of economic governance variables on a country-bycountry basis. The OECD compiles data on aid for trade programs and allocations. While these data sources have weaknesses, they permit analysis of how different policies and changes in the level of indicators impact on trade. The African Development Bank has developed a database monitoring applied (bilateral) visa regimes of African countries. UNCTAD, in collaboration with the AfDB and other international organizations, has been working on updating data on NTMs, which is the basis for the analysis of Cadot and Gourdon (2016) mentioned above. The work done by Tarr and coauthors illustrates that much can also be done through project-specific data collection efforts utilizing expert interviews and surveys.

Recent research focusing on NTMs and the implications of "non-integration" of African markets (e.g., Balchin et al. 2015; Dihel and Goswami, 2016; Cadot and Gourdon, 2014, 2016; Brenton and Hoffman 2016, Storeygard, 2016) shows what can be done with extant data and how this can be complemented at low cost by information using social media and mobile telecommunications. Such research can build on the Trade Costs Database that has been compiled by the UN Economic and Social Commission for Asia and the Pacific (UNESCAP) and the World Bank that contains bilateral trade costs for manufacturing and agricultural products for more than 150 countries, including Africa (Arvis et al., 2016). This dataset is updated annually and tracks the evolution of trade costs through time in different income groups and regions.

But it is necessary to go further and pursue more granular research. This requires collecting more detailed information on regulatory regimes and institutions, both those that impact across sectors such as the efficiency of the judiciary or competition policy - and those that are sector-specific. This is particularly needed to assess progress in realization of regional integration, as that agenda revolves in large part around reducing the effects of differences in regulatory regimes. Here again progress has already been made that can be built upon. An example is the effort by the OECD to characterize the constituent elements of the TFA into indicators that can be monitored over time and used for empirical analysis (Moïsé and Sorescu, 2013). In the African context, a noteworthy initiative is the bi-annual East African Common Market Scorecard report (World Bank and EAC Secretariat, 2016) which contains information on the extent to which prevailing laws and regulations discriminate against foreign providers seeking to operate in each EAC member state. The report provides detailed

\footnotetext{
${ }^{15}$ Such analysis has been undertaken for tariffs. For example, see Nicita, Porto and Olarreaga (2014) for an analysis of the distributional impacts of the structure of import tariffs prevailing in African countries.
} 
documentation allowing assessment of the consistency of prevailing legislation and regulations with the commitments that countries have made as EAC members. A similar effort could be undertaken for other RECs and the CFTA. ${ }^{16}$

Monitoring and evaluation of trade integration initiatives and projects is perhaps one of the most obvious areas for additional research. Available papers on Africa (e.g., Njinkeu et al. 2008) are limited in terms of methodologies and data used. Some policy areas such as liberalization of services markets are clearly complex as a result of the multidimensionality of relevant regulatory regimes and the different modes of supply that may be used by providers of services. But even in an area that appears much more straightforward such as trade facilitation - there may be significant political economy complications in implementing reforms. An example is provided by the various trade corridor projects that are being pursued in different regions in Africa. The Abidjan-Lagos corridor is illustrative. This handles more than two-thirds of West African trade, transport and transit activities. A major ongoing project aims to improve the road infrastructure between Abidjan and Lagos as well as modernizing the ports in Côte d'Ivoire, Ghana, Togo, Benin and Nigeria. Soft infrastructure determinants of the operation of the corridor include customs operations at borders, port efficiency, and reduction of checkpoints and roadblocks along the corridor. A significant share of the total project costs is devoted to road construction, all of which was concluded on target. However, there was a lot of heterogeneity in terms of progress towards performance targets such as dwell times in the ports and border crossing times. This reflected limited progress on 'soft' aspects of trade facilitation, including coordination and cooperation within and across governments and the development agencies involved and a lack of attention for the political economy context (Njinkeu and Hartmann, 2015). More research to inform project design with a view to creating stronger incentives for collaboration and interaction within and between government agencies, as well as mechanisms to generate effective and timely feedback on gaps are important to support efforts to reduce trade costs and regional integration. We return to this below.

\section{Inter-REC liberalization issues}

The inter-REC liberalization effort that is the core dimension of the TFTA and the CFTA raises research questions that overlap to a great extent with those discussed in other sections of this paper. However, several distinct issues are particularly salient: how to remove inter-REC tariffs; agreeing on rules of origin; issues relating to regulatory cooperation; and the salience of pursuing "text book" forms of regional integration - the "linear model" in which regional integration proceeds from free trade agreements to customs unions, common markets and economic and monetary union.

Starting with the last, moving beyond free trade agreements to a custom union entails a need for common institutions to manage the distribution of tariff revenue collected on imports from nonmembers and to implement a common external trade policy. Africa already has three operational customs unions: EAC, ECOWAS and SACU with a common external tariff (they do not have a common external trade policy towards services). The CFTA aims to create a single continental market for goods and services, with free movement of business persons and investments, as a stepping stone towards the eventual establishment of a continental customs union. The achievement of a CFTA would in itself already be a major achievement and it is a hugely ambitious endeavor. In our view research should focus on studies that can help guide and inform the process of removing barriers to

${ }^{16}$ As noted previously, the monitoring report by the AfDB, African Union and UNECA does not do this. 
intra-regional trade and investment as opposed to issues relating to the institutional dimensions that arise in going further than a FTA. While a common external tariff (CET) would facilitate intra-CFTA trade by obviating the need for rules of origin, the political economy challenge of agreeing on a CET for much of Africa is likely to be a politically fraught process. This was illustrated by the complex and long drawn out negotiations on establishing the CET for ECOWAS.

\section{Tariffs and related policies}

As mentioned earlier, average external tariffs of the different African RECs are relatively high and differ across RECs. A CFTA implies that members will no longer impose tariffs on imports from other CFTA members (and in the case of countries belonging to customs unions, cease to apply their respective CET to CFTA members). While this must be accompanied with rules of origin -see below as long as these are not designed to be protectionist and cumbersome, tariff removal will greatly facilitate trade, in part by reducing incentives for smuggling and informal trade. At the same time, officials will confront opposition from industries and persons currently protected by high tariffs. The political economy dynamics of tariff liberalization are well understood - where research can help is by assessing the net effect of tariff removal on intra-CFTA trade on a wide range of industries. Firms are both buyers and sellers of goods, and will benefit from tariff reduction on their inputs. Those firms that are the most productive will benefit from being able to export without confronting tariffs. Consumers will gain through lower prices and greater choice. Partial equilibrium tools to assess the first order impacts of changing (removing) tariffs are readily available (as are CGE models that allow general equilibrium effects to be assessed). The value added that researchers can bring is by considering the interaction between tariffs and related policies - e.g., the AVE of quantitative restrictions (product-specific import or export bans; local content incentives) and differential tax/subsidy policies for inputs and outputs.

Nigeria illustrates that analysis of the tariff agenda cannot be delinked from sector specific and general fiscal incentives for both investment and operations. There is major knowledge gap in this regard concerning applied policies that have a bearing on firm-level incentives. A few studies have attempted such assessments. Oyejide et al. (2013), for example, present a detailed analysis of government interventions in rice in Nigeria. This highlighted the presence of various market failures calling for intervention but concluded that applied trade policies - a prohibition on imports of rice - was welfare reducing as a result of opaque and discriminatory application of the policy and the granting of selective exemptions, opening the policy to corrupt practices. Most of the benefits (rents) of the ban did not accrue to smallholder farmers. More important for domestic productive capacity were post-harvest output losses due to inadequate basic transport infrastructure and preservation and distribution facilities. What is needed is applied research that characterizes the magnitude and distribution of the rents and incidence of the associated costs associated with both tariffs and related incentive policies: granular, partial equilibrium modelling of sector-specific effects of policies and their reforms impacts. Examples of such analysis include Von Uexkull et al. (2014) and Njinkeu et al. (2017), who used the Tariff Reform Impact Simulation Tool (TRIST) microsimulation modelling based on enterprise survey data to analyze the impact of incentive policy reforms for Nigeria. ${ }^{17}$

\footnotetext{
${ }^{17}$ See http://go.worldbank.org/2X1IC75J40 for details on TRIST.
} 


\section{Rules of origin}

Free trade agreements require the parties to agree on the rules (regulations) that will determine whether a product is eligible to benefit from whatever provisions are embodied in the agreement. This applies to both goods and services. ${ }^{18}$ Thus, to be eligible for preferential market access benefits an exporter will need to document that the product has been produced in an eligible country. Such preferential rules of origin (RoO) have been the focus of much lobbying and policy debate. To a significant extent the more difficult it is for exporters to satisfy RoO - the more restrictive or stringent the RoO are - the less valuable preferential access will be. RoO differ across countries and products. The most commonly used approaches are based on whether a processing operation satisfies: (i) an ad valorem percentage; ${ }^{19}$ (ii) a change in tariff heading (based on the Harmonized Commodity Description and Coding System-the HS); or (iii) involves a specific technology, method or process.

Economic research on RoO has largely been focused on estimating their trade-distorting effects, often using methodologies that are centered on determining the ad valorem tariff equivalents of RoO. This type of empirical research has to our knowledge not focused on African RECs. ${ }^{20}$ The work on Africa has been more qualitative in nature (e.g., Erasmus et al. 2006) and focused on inconsistencies and trade costs created by multiple REC memberships. Empirical research could usefully focus on the drivers of differences and changes in RoO across RECs. There has been considerable evolution in the technique and content of drafting RoO in PTAs (Hoekman and Inama, 2017). In Africa, SADC and COMESA, for example, have adopted simple rules such as across-the-board percentage criteria that mirror those in the US trade preference program or the change of tariff heading criteria following the EU model. Over time product-specific rules of origin (PSRO) were developed, again borrowing from US and EU models. However, this led to differences between rules applied across RECS. SADC relies more intensively on PSRO that are more restrictive than COMESA. Although in principle EAC and COMESA RoO are similar, in practice they differ substantially (Naumann, 2014).

The establishment of the TFTA and the CFTA require participating countries to agree on a common set of RoO. Developments in other regions that have led to some simplification and streamlining of RoO may provide templates that African RECs should assess with a view to determining if they can guide their RoO. For example, the EU and the US have reduced the use of methodologies based on calculations of value added in favour of a value of materials used ad valorem percentage calculation. Crivelli and Inama (2017) document a trend towards convergence and simplification of RoO in a number of recent PTAs involving the EU and the US. Two WTO Ministerial Decisions on preferential RoO for LDCs call for rules that permit the use of up to 75 percent of "non-originating" materials in the value of the product or a simple change of tariff sub-heading as criteria determining origin. Such simplification could also be pursued in the African integration context - helping to both reduce costs for firms directly through simplified, more liberal RoO and indirectly, through harmonization of rules applying to intra-African trade with those applied in major external markets (especially the EU). Quantifying the potential benefits of applying such simplified RoO in the context of the CFTA would help to limit the extent to which RoO will act as NTMs and thus reduce the benefits for intra-regional

\footnotetext{
${ }^{18}$ See Latrille and Lee (2012) for a discussion of RoO for services in a large number of trade agreements.

${ }^{19}$ This can be based on whether a minimum amount value added is embodied in a product as the result of activities in the last country in which the product was processed/produced according to different calculation techniques; whether a maximum percentage of non-originating materials has not been exceeded; or a minimum percentage of originating inputs has been used in the manufacturing of the finished product.

${ }^{20}$ Recent examples of non-Africa research include Cadot and Ing (2016) and Conconi et al. (2016).
} 
trade. Techniques to undertake such analysis have been developed - e.g., Cadot and Ing (2016) - but have to our knowledge yet to be applied to African contexts.

\section{Inter-REC regulatory cooperation and reform}

The regional trade integration agenda is increasingly centered on reducing the trade costs created by regulatory diversity. As African countries move forward with the CFTA work program, inter-REC cooperation on regulatory matters will assume greater prominence. Research is needed to map the regulatory landscape prevailing within RECs and how this impacts on trade costs for agents along the supply chain, from producers to consumers. Such research should be sector- and country/RECspecific. Countries address domestic policy objectives in different ways, the costs (and benefits) of making regulatory changes vary depending on the sectors and the regulatory systems. For most countries and sectors a lack of coherence and compatibility among different regulatory systems can exacerbate trade costs.

The research agenda here encompass assessments of the trade impact of existing policies towards both goods and services - e.g., as in Cadot and Gourdon (2014; 2016) or Hoekman and Shepherd (2017) - and potential alternative types of regulatory cooperation such as harmonization, alignment on international standards, mutual recognition/equivalence, and measures to enhance transparency. Existing work on the trade effects of regulatory heterogeneity for developed (OECD) economies need to be undertaken in the African context. Research to identify the costs of regulatory heterogeneity generally distinguishes three categories of costs-specification costs (the actual costs of complying with different sets of regulations), conformity assessment costs (costs involved in demonstrating conformity with these regulations), and information costs (costs related to obtaining adequate information and transparency with respect to regulations and regulatory motivations, which affords greater predictability and avoids arbitrariness) - see van Tongeren et al. (2015). Each type of cost can be fixed or variable and is generally country and sector-specific and varying over time. Van Tongeren et al. (2009), Beghin et al. (2012; 2015) and Disdier and Marette (2010) develop analytical frameworks that can be used to measure welfare effects of regulatory NTMs that are intended to address market failures and associated externalities. These can be used to assess what types of reforms and/or investments will have the greatest potential in lowering trade costs and increasing real incomes.

A consistent cross-border African trade bottleneck decried by traders is the deficit in energy and infrastructure to which governments, bilateral donors, and multilateral development banks have responded by major investments but with minimal impact in terms of cost reduction and efficiency. Research has established that such investment needs to be complemented by policy reform, particularly on cooperation and coordination (Freund and Rocha, 2011; Hoekman and Nicita, 2011; Portugal-Perez and Wilson, 2012). Although reducing barriers to trade is a necessary condition to reduce costs, poor regulatory services and regulatory heterogeneity between trading countries are factors that can also act as de facto barriers. For example, if foreign professionals already licensed to practice in some jurisdictions are still required to go through cumbersome processes to practice in other African countries cross-border trade will be hampered. These regulatory heterogeneities impose costs on professionals in the form of expenses for competence tests, re-qualifications, re-training and completing additional licensing requirements (Dihel and Goswami, 2016). ECOWAS has realized 
some progress on regulatory cooperation in telecom and energy services; but the overall benefits of such cooperation are not yet well understood and accepted. Research to measure and assess the effects of regulatory heterogeneity, efforts to pursue intra- or cross-REC cooperation, and the incentives of regulatory agencies to pursue cooperation is quite limited in the African context.

Reducing the costs of trade is what trade agreements are designed to do, but this is much easier to conceptualize and negotiate if the focus is on reciprocal removal of import tariffs. Joint action to streamline administrative and regulatory procedures or to cooperate on joint infrastructure projects such as transport corridors or connecting energy grids is a much more complex endeavor. Projects that entail actions that are local or regional in nature may be better pursued through mechanisms that mobilize and empower local stakeholders that internalize the costs and benefits as opposed to through the apparatus of a trade agreement which by its nature involves central governments. As discussed below, such local or regional public good provision approaches have been used to good effect in the East African context and deserve greater attention by researchers.

\section{Trade-governance linkages}

Extensive research has documented the importance of good governance for economic development-political stability, rule of law, control of corruption. Such factors impact on the gains from liberalization and may reduce net gains significantly. International economic integration can be used as one instrument to improve economic governance at the sector-specific or economy-wide level through agreement on enforceable rules of the game or the creation of common institutions. The research question here is where rules/cooperation could have significant payoffs in the African context and how they could be structured.

Beverelli, Fiorini and Hoekman (2017) provide an example of the type of research that could inform regional integration initiatives. They use industry level data for 58 countries to assess the effect of STRIs on productivity in downstream manufacturing as a function of the quality of economic governance that prevails in countries. They find that the effects of services trade restrictions are mediated by the quality of domestic economic governance. Countries with high STRIs are likely to benefit more from lowering barriers to trade in services if the quality of institutions, as proxied by indicators such as control of corruption and rule of law, is good. Conversely, if economic governance is weak, a country will benefit less from reducing average STRIs. An explanation for the sensitivity to institutional quality is that provision of many services requires a physical presence so that foreign firms will consider the business environment they must operate in, and not just the level of the STRI.

The relationship between institutional quality and STRIs is illustrated in Table 1 for seven SSA countries in the sample analyzed by Beverelli et al. (2017). For each country, the effect of STRIs on labor productivity in downstream sectors is calculated for the largest and the $2^{\text {nd }}$ largest manufacturing industry in the country - see Annex 1 for a summary description of the methodology used. "Impact" in Table 1 refers to the estimated percentage change in sectoral labor productivity of removing all barriers to FDI in financial, transport, communication and business services, as measured by the World Bank's STRI for mode 3. The column "current institutions" is simply the estimated impact, while the numbers in the columns labelled "High Institutions (Africa)" and "High Inst. (DNK) measures the effect on labor productivity under counterfactual scenarios where the governance variable (rule of law, regulatory quality, control of corruption, respectively, in panel A, B and C) is set at level of the African country with the best performance on each respective variable or at the level of 
Denmark, generally the highest performing country in the world in terms of economic governance indicators. The last two columns report the ranking of countries in terms of STRI levels (openness) and governance quality.

Table 1: Impact of removing services FDI barriers on downstream labor productivity (\% change)

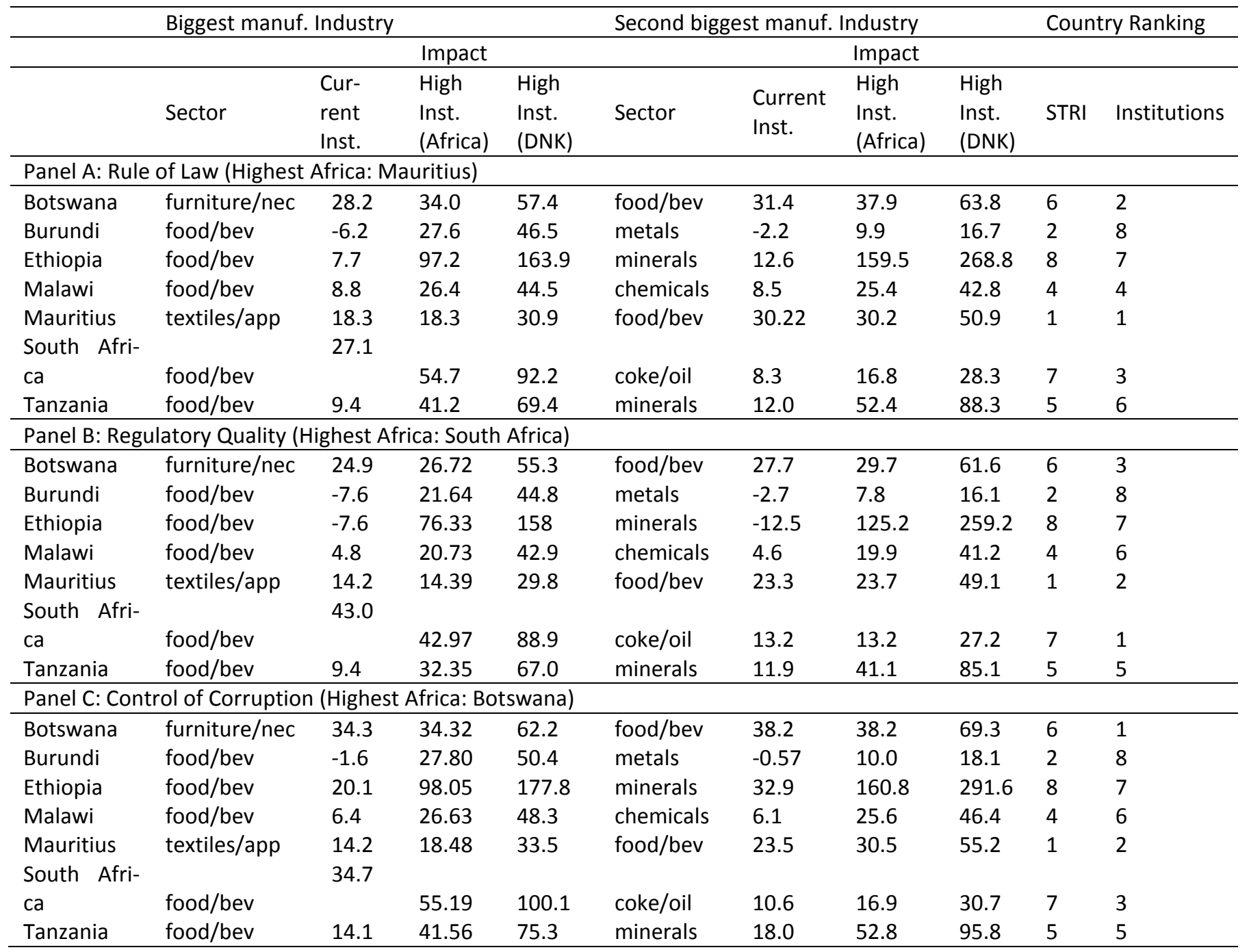

Notes: Source of governance variables: World Bank Governance Indicators. Services trade policies from the World Bank Services Trade Restrictiveness Database. Labor productivity (output per worker) from UNIDO industrial statistics database. Sectors based on ISIC 2-digit classification (Food/Bev: 15+16; Textiles/Apparel: 17+18+19; Furniture/nec: 36+37; Metals: 27; Mineral Products: 26; Chemicals: 24; Coke/Oil: 23). "Current institutions" estimates are statistically different from zero only for Botswana, Mauritius and South Africa.

Source: Fiorini and Hoekman (2016), based on the analysis of Beverelli, Fiorini and Hoekman (2017).

Food processing tends to be the largest or second largest manufacturing activity in the countries in the sample. Botswana and Mauritius have the best governance of this set of countries. If Botswana were to remove all mode 3 barriers, this would generate a productivity increase in the food and beverages sectors of some 24 to 34 percent, depending on the governance indicator that is used. Similar magnitude effects are estimated for Mauritius and South Africa. However, for the other countries, the impacts would be substantially smaller, despite the level of mode 3 restrictions being higher 
than in the other three countries. If, however, the four countries with weaker governance were to improve their institutional environment to that prevailing in the best performing Sub-Saharan African country the positive productivity impact of services liberalization would increase by a magnitude of four to ten. Moving towards the Danish benchmark would increase impacts by another 50 to 100 percent. While the magnitudes of the estimates are only indicative - the estimates for the four countries with weaker governance are not statistically significant - the results are nonetheless informative: they illustrate the importance of economic governance as a determinant of the gains from trade liberalization. The implication for national policy and regional integration initiatives is that attention should focus on governance, not just reducing STRIs.

This type of analysis is informative in pointing to the importance of governance quality as a determinant of the effects of services trade policy, and thus potential trade reforms, but it is only a first step. We do not know, for example, to what extent the country-level governance variables reflect sectorspecific policies. Dealing with corruption or enhancing the rule of law clearly is important but from the perspective of the design of trade integration efforts such as the CFTA and sub-regional arrangements such as the EAC, ECOWAS, etc. it is necessary to know if and how specific sectoral policies interact with trade policies or customs/border clearance procedures. The types of scorecard report prepared for the EAC can be used to construct policy indicators and 'unpack' how different dimensions of the business environment and economic governance variables impact on economic performance.

\section{Design of mechanisms for stakeholder engagement and feedback}

Many NTMs have been put in place for good reasons, e.g., to address market failures and pursue specific social objectives. This implies that regional integration has the potential to be welfarereducing if it results in constraining the efficacy of specific NTMs in attaining their purpose. Policy coherence requires that efforts to reduce trade costs do not undercut the realization of the social objectives that motivate the various NTMs that a country has put in place. An effective trade facilitation agenda, for example, must involve stakeholders to identify how best to reduce trade costs. There is no one size fits all-different factors and circumstances will prevail across countries, transit corridors, and regions and ports within countries.

Regional market integration efforts are most likely to be successful when clear leadership emerges in government, effective mechanisms exist for the private sector to participate, and evidence-informed consensus-building processes are put in place to broker dialogue among the various interest groups. The majority in the public and private sectors is eager to see real improvement; what is needed is to establish platforms to help organize and empower pro-reform stakeholders to overcome the vested interests. A framework for peer-to-peer learning among government officials, business and civil society that encourages stakeholders from different sectors to debate and cross-fertilize ideas, concepts and methods and to better understand the consequences of current modes of operation can empower reforms by generating peer-pressure and increasing accountability (Hoekman, 2014).

Most regional integration-related reform programs focus on technical dimensions and neglect political economy considerations - understanding who benefits and who loses, or who perceives they will benefit or lose. This requires identifying the interests of the different stakeholders, how they are represented, how pro-reform coalitions can be built and strengthened and how anti-reform interests can be accommodated. The organized private sector will play an effective and proactive role if and 
when they see clear business opportunities. In East Africa, as Kenyan firms have increased their investment in other EAC Partner States they have increasingly lobbied their government for implementing the EAC protocols of direct relevance to their sectors. This has been particularly true for trucking companies that heavily invested and have aggressively lobbied for more competition and improved efficiency. They have generally supported efforts to eliminate restriction to foreign competition in the transport sector. Other businesses that are more focused on the domestic market have acted in a different direction. For example, the Kenya International Freight Forwarders and Warehousing Association and Tanzania Freight Forwarders Association have seen regional integration in the transport sector as a threat to their business; and as a result, they have been lobbying for lesser competition. Members of these associations want to prevent foreign clearing and forwarding agents from handling domestic cargo. Other freight forwarders, by contrast, see it as an opportunity for partnerships and mergers between the Tanzanian and/or Kenyan forwarders and their counterparts in the landlocked countries. ${ }^{21}$

Where Apex business association bodies have been effective, such as in East Africa, they have supported harmonized business processes and deeper engagement with governments. These include the East Africa Business Council, the Kenya Manufacturing Association, and the Kenya Private Sector Alliance. The transport sector associations like Kenya Shippers Council and the Uganda Shippers Council have made the Shippers Council of East Africa a powerful advocate for regional integration. EAC member states are making some progress on regulatory harmonization in the transport sector, particularly axle load harmonization through which all EAC member states use the same policy for axle load. Such pragmatic reliance and pursuit of 'variable geometry' can be powerful in pursuing lower trade costs. Tanzania, and to some extent Burundi, has for a long-time preferred a slower pace in integration of EAC than Kenya, Rwanda, and Uganda.

Heads of States of the latter three countries have supported a variable geometry-based time table in such areas as infrastructure development, single tourist visa, and enhanced labor mobility. This has facilitated the implementation of a Single Customs Territory along the Northern Corridor and has led to reduced border crossing times, elimination of many weighbridges and police checkpoints on the roads, and growing compliance with weight restrictions. For example, the Regional Customs Transit Guarantee (RCTG) scheme covers transit goods from or to the ports and has eliminated multiple national transit guarantees. The single RCTG is accepted throughout the customs territory; this has significantly enhanced intra-EAC trade and lowered expenses for businesses particularly on the Northern Corridor. This in turn has had positive spillover effects on Tanzania and Burundi, as well as SouthSudan and Eastern DRC. Progress on the central corridor has been more limited.

Most stakeholders engaged in cross border trade are familiar with prevailing procedures and know how to operate and trade profitably. Prioritizing the technical aspects of trade facilitation overlooks the fact that procedural change will shift the costs and benefits. This can result in attention shifting away from those actors who may feel threatened by the proposed changes. A common mistake is to confound the problem with capacity constraints that can be alleviated by funding for trade capacity building activities to support trade facilitation. While capacity weaknesses are undeniable in Africa, adopting a narrow focus on such constraints neglects the need for analysis and understanding of the role of vested interests. An overall supply chain approach is needed that goes beyond targeting technical capacity limitations to one that spans the role of all the stakeholders, including financial

${ }^{21}$ Kunaka et al. (2016) discuss policies to facilitate the operation of trucking service providers in East Africa. 
institutions, clearing and forwarding agents, import competing private companies, and parastatal entities that may be benefiting from the existing policy and regulatory framework and may actively oppose any change (see Njinkeu and Hartman, 2015).

At the continental level, a framework for a broad-based consideration of the trade cost reduction agenda is the Africa Trade Facilitation Forum (ATFF) organized by the African Union Commission which brings together a diverse stakeholders group to review the various dimensions of trade facilitation. The ATFF is the first platform organized at ministerial level bringing together CEOs and executives from the private sector, development banks, parliamentarians, civil society leaders, academia, international development agencies and the media. This multi-stakeholder platform enables consideration of practical policies and actions for implementing trade facilitation programs. Deliberations at the first meeting of this body underscored the importance of the ATFF to be made a permanent Pan-African platform for advancing intra-African trade facilitation dialogue among multi-stakeholder groups. ${ }^{22}$ The ATFF would be even more effective if preceded by similar process at the level of each regional economic community. Initiatives such as the ATFF need to be supported by research on the channels through which reduction in trade costs promotes trade and increases productivity.

Ultimately successful regional integration requires profiling existing interests, motivations, and priorities, incentives and pressures under which the stakeholders operate. There is a dearth of detailed political economy analyses of trade cost determinants and trade facilitation incentives in Africa. ${ }^{23}$ Such analysis will require high level commitment to provide the necessary political support to undertaking political-economy focused research that includes a focus on all the stakeholders including those operating informally. Opposition to reform often arises from lower levels in the bureaucracy and those operating at the margins of the formal structures. Better understanding and consideration of how the institutional power play between all stakeholders can be accommodated is necessary. A related challenge is designing interventions that will do the most to support trade expansion and thus associated investment and employment creation. From a policy identification and accountability perspective deliberative mechanisms that involve stakeholders can be valuable in bringing together a constituency that will actively support reforms and help avoid a narrow technical approach to trade facilitation. Research is needed on how mechanisms such as the ATFF can be designed in SSA countries to operate efficiently and effectively; including insulating the process against capture by vested interests, generating the information that is needed for informed discussion and decisionmaking (often missing or inaccurate at present) and identifying how legal and regulatory regimes negatively impact on sound business planning, raise operating costs and thus undermine competitiveness. This is in part a mechanism design question. It includes issues such as the appropriate legal and regulatory regimes, and assessing how stakeholders can be given greater certainty that implementation of agreed action agendas will be monitored and there will be greater accountability for results.

\section{Concluding remarks}

"Integrating Africa" is an enormous challenge that has a large number of dimensions. A challenge for research in support of African regional integration is to help "move the needle" in making progress in achieving regional integration objectives - including by monitoring the extent of progress and

\footnotetext{
${ }^{22}$ See http://www.uneca.org/stories/call-arms-underlines-opening-africa-trade-facilitation-forum.

${ }^{23}$ See, however, Kirk (2016), Swinnen and Janssen (2016) and other contributions in Brenton and Hoffman (2016) and Lui and Siziba (2012).
} 
evaluating effects. As noted by many observers - e.g., De Melo and Tsikata (2015) and the contributors to Brenton and Hoffman (2016) - the economic potential associated with regional integration is substantial. There is now a more serious effort by African leaders to realize this potential, stimulated in part by greater engagement by the private sector and a willingness to engage in forms of cooperation that are not limited by an exclusive focus on pursuit of the "linear model" of integration (Karingi and Davis, 2016). Examples include the focus on making corridors work more efficiently, to facilitate trade, and cross-border projects that provide sub-regional public goods (energy projects; joint infrastructure).

Reducing trade costs through elimination of tariffs, addressing NTBs, liberalization of trade in services, engaging in regulatory cooperation and pursuit of trade facilitation broadly defined are complex endeavors. In many of the policy areas that are relevant to integrating African markets multiple government agencies and regulatory bodies play a role. This is the case in particular for policies that affect the ability of services providers to offer their products in foreign markets. Standard types of economic analysis of the effects of trade costs and regional integration initiatives that center on estimating the effects of reforming trade policies remain important and there has arguably been too little such research. But research arguably should go beyond such analysis to be more relevant to policymakers, the business community and consumers/workers/citizens.

Much research has been done in recent years that has documented the economic importance of trade costs and measures to facilitate trade. Much of this has been 'macro' in nature in the sense of using firm-level data or trade data to assess the effects of country-level policies or trade policyrelated dimensions of the investment climate. The agenda looking forward is to do more to inform the design of regional integration initiatives - including of a plurilateral or variable geometry nature that is not necessarily associated with the 'linear model' of economic integration - and assess the effects of regional initiatives that aim to lower trade costs. This applies to trade in services as well as goods. Better understanding of the role that services - and services trade policies - play as determinants of trade operating costs and how this is affected by economic governance and sectoral regulation is an important area for research.

\section{References}

Ackah, C. and O. Morrissey, 2005, "Trade policy and performance in Sub-Saharan Africa since the 1980s," CREDIT Research Paper, No. 05/13.

Afesorgbor, S. 2017. "Revisiting the Effect of Regional Integration on African Trade: Evidence from Meta-Analysis and Gravity Model," Journal of International Trade and Economic Development, 26(2): 133-53.

African Union Commission, 2015, Agenda 2063: The Africa We Want. At http://www.un.org/en/africa/osaa/pdf/au/agenda2063.pdf.

African Union, AfDB and UNECA, 2016, Africa Regional Integration Index Report 2016.

Arnold, J., A. Mattoo, and G. Narciso. 2008. "Services Inputs and Firm Productivity in Sub-Saharan Africa: Evidence from Firm Level Data." Journal of African Economies 17 (4): 578-99.

Arvis, J. F., Y. Duval, B. Shepherd, and C. Utoktham. 2016. "Trade Costs in the Developing World: 1995-2010," World Trade Review, 15(3): 451-74.

Balchin, N., L. Edwards and A. Sundaram, 2015, "A Disaggregated Analysis of Product Price Integration in the Southern African Development Community," Journal of African Economies, 24 (3): 390-415.

Balchin, N., B. Hoekman, H. Martin, M. Mendez-Parra, P. Papadavid and D. te Velde. 2016. "Trade in Services and Economic Transformation," London: Overseas Development Institute. 
Balistreri, E., D. Tarr and H. Yonezawa; 2015, "Deep Integration in Eastern and Southern Africa: What are the Stakes?" Journal of African Economies; 24 (5): 677-706.

Balistreri, E., J. Jensen and D. Tarr, 2015, "What Determines Whether Preferential Liberalization of Barriers against Foreign Investors in Services Are Beneficial or Immiserizing: Application to the Case of Kenya," Economics: The Open-Access, Open Assessment E-Journal, 9(42): 1-134.

Balistreri, E., M. Maliszewska, I. Osorio-Rodarte, D. Tarr and H. Yonezawa (forthcoming) "Poverty and Shared Prosperity Implications of Reducing Trade Costs Through Deep Integration in Eastern and Southern Africa," Journal of African Economies.

Beghin, J. M. Maertens and J. Swinnen, 2015. "Nontariff Measures and Standards in Trade and Global Value Chains," Annual Review of Resource Economics, Annual Reviews, 7(1): 425-50.

Beghin, J., A. Disdier, S. Marette and F. van Tongeren, 2012, "Welfare costs and benefits of nontariff measures in trade: a conceptual framework and application," World Trade Review, 11: 356-75.

Beverelli, C., M. Fiorini, and B. Hoekman. 2017. "Services Trade Restrictiveness and Manufacturing Productivity: The Role of Institutions," Journal of International Economics 107: 166-82.

Beverelli, C., S. Neumueller and R. Teh, 2015, "Export Diversification Effects of the WTO Trade Facilitation Agreement," World Development, 76: 293-310.

Bombarda, P., and E. Gamberoni, 2013, "Firm Heterogeneity, Rules of Origin and Rules of Cumulation," International Economic Review 54, 307-28.

Borchert, I. B. Gootiiz and A. Mattoo, 2014. "Policy Barriers to International Trade in Services: Evidence from a New Database," World Bank Economic Review, 28(1): 162-88.

Borchert, I. B. Gootiiz, A. Grover and A. Mattoo, 2017, "Services Trade Protection and Economic Isolation," The World Economy, doi: 10.1111/twec.12327.

Brenton, P. and B. Hoffman (Eds.). 2016. Political Economy of Regional Integration in Sub-Saharan Africa. Washington, DC: World Bank.

Brenton, P. and G. Isik (Eds.), 2012, De-Fragmenting Africa: Deepening Regional Trade Integration in Goods and Services, World Bank, Washington DC.

Cadot, O., de Melo, J., 2008. "Why OECD countries should reform their rules of origin," World Bank Research Observer (23): 77-105.

Cadot, O. and J. Gourdon, 2014, "Assessing the Price-Raising Effect of Non-Tariff Measures in Africa," Journal of African Economies, 23 (4): 425-63.

Cadot, O. and J. Gourdon, 2016, "Non-tariff measures, preferential trade agreements, and prices: new evidence," Review of World Economics, 152(2): 227-49.

Cadot, O., C. Carrere, J. De Melo and B. Tumurchudur, 2006, "Product-specific rules of origin in EU and US preferential trading arrangements: an assessment," World Trade Review, 5(2): 199224.

Cadot, O. and L. Ing, 2016, “How Restrictive are ASEAN's RoOs?” Asian Economic Papers, 15(3): 11534.

Christ, N. and M. Ferrantino. 2011. "Land Transport for Exports: The Effects of Cost, Time, and Uncertainty in Sub-Saharan Africa," World Development 39(10): 1749-59.

Cissokho, L., J. Haughton, K. Makpayo and A. Seck, 2013, "Why Is Agricultural Trade within ECOWAS So High?" Journal of African Economies, 22 (1): 22-51.

Conconi, P., M. García-Santana, L. Puccio and R. Venturini, 2016, "From Final Goods to Inputs: The Protectionist Effect of Rules of Origin," CEPR Discussion Paper 11084.

Crivelli, P. and S. Inama, 2017, "Comparative analysis of RoO in recent FTAs," UNCTAD and EUI, Excel workbook and related tables. In progress.

De Melo, J. and Y. Tsikata, 2015. "Regional integration in Africa: challenges and prospects," in C. Monga and J. Lin (eds.), The Oxford Handbook of Africa and Economics, Volume 2: Policies and Practices. Oxford: Oxford University Press.

Dihel, N., and A. Goswami (Eds.) 2016. From Hair Stylists and Teachers to Accountants and Doctors The Unexplored Potential of Trade in Services in Africa. Washington, DC: World Bank. 
Disdier, A. and S. Marette. 2010. "The combination of gravity and welfare approaches for evaluating nontariff measures." American Journal of Agricultural Economics 92(3): 713- 26.

Djankov, S., C. Freund and C. Pham, 2010. "Trading on Time," Review of Economics and Statistics, 92(1): 166-73.

Eaton, J., and S. Kortum. 2001. "Trade in Capital Goods." European Economic Review 45 (7): 11951235.

Estevadeordal, A. and K. Suominen, 2008, "Trade Effects of Rules of Origin" in A. Estevadeordal and K. Suominen, (eds.), Gatekeepers of Commerce: Rules of Origin and International Economic Integration. Washington DC: IDB.

Fiorini, M. and B. Hoekman, 2017. "Economic Governance, Regulation and Services Trade Liberalization," EUI Working Paper RSCAS 2017/27.

Erasmus, H., F. Flatters and R. Kirk, 2006, "Rules of Origin as Tools of Development? Some Lessons from SADC," in Cadot, O., A. Estevadeordal, A. Suwa-Eisenmann and T. Verdier (Eds.), 2006, The Origin of Goods, CEPR and Oxford University Press.

Francois, J. and B. Hoekman, 2010, "Services Trade and Policy," Journal of Economic Literature, 48(3): 642-92.

Francois, J. and M. Manchin, 2013, "Institutions, Infrastructure, and Trade," World Development, 46(C): 165-75.

Frazer, G. and J. van Biesebroeck, 2010, "Trade Growth under the African Growth and Opportunity Act," Review of Economics and Statistics, 92 (1), 128-144.

Freund, C. and D. Pierola, 2008, "Export surges: the power of a competitive currency," Policy Research Working Paper 4750, The World Bank.

Freund, C. and N. Rocha, 2011. "What constrains Africa's exports?," World Bank Economic Review, 25(3): 361-86.

Geda, A. and E. Seid, 2015, "The potential for internal trade and regional integration in Africa," Journal of African Trade 2(1-2): 19-50.

Geda, A. and H. Kibret, 2008. "Regional integration in Africa: a review of problems and prospects with a case study of COMESA," Journal of African Economies, 17 (3), 357-94.

Hillberry, R. and X. Zhang, 2015, "Policy and Performance in Customs: Evaluating the Trade Facilitation Agreement," World Bank Policy Research Working Paper 7211.

Hoekman, B. 2014. Supply Chains, Mega-Regionals and Multilateralism: A Road Map for the WTO. London: CEPR. At: http://voxeu.org/content/supply-chains-mega-regionals-and-multilateralismroad-map-wto.

Hoekman, B. and S. Inama. 2017. "Rules of Origin as Non-Tariff Measures: Towards Regulatory Convergence?" EUI Working Paper.

Hoekman, B. and A. Nicita. 2011. "Trade Policy, Trade Costs and Developing Country Trade." World Development, 39(12): 2069-79.

Hoekman, B. and B. Shepherd. 2015. "Who Profits from Trade Facilitation Initiatives: Implications for African Countries," Journal of African Trade, 1(2): 51-70.

Hoekman, B. and B. Shepherd, 2017. "Services Productivity, Trade Policy and Manufacturing Exports," The World Economy, doi: 10.1111/twec.12333.

Jafari, Y. and D. Tarr, 2017, "Estimates of Ad Valorem Equivalents of Barriers against Foreign Suppliers of Services in Eleven Services Sectors and 103 Countries," The World Economy, 40(3): 544-73.

Jensen, J., T. Rutherford and D. Tarr, 2010, "Modeling Services Liberalization: the Case of Tanzania," Journal of Economic Integration, 25 (4), December, 644-675.

Kaplinsky, R. and M. Morris, 2015, "Thinning and Thickening: Productive Sector Policies in the Era of Global Value Chains," European Journal of Development Research, doi:10.1057/ejdr.2015.29.

Karingi, S. and W. Davis, 2016, "Towards a Transformative African Integration Process: Rethinking the Conventional Approaches," presented at the AERC research workshop on "Integrating African Markets: The Way Forward', May 29-June 2, Nairobi, Kenya. 
Kirk, R. 2016. "The Political Economy of Trade Facilitation in Eastern and Southern Africa," in Brenton and Hoffman.

Kunaka, C., G. Raballand and M. Fitzmaurice, 2016, "How trucking services have improved and may contribute to economic development: The case of East Africa," UNU-WIDER working paper 152.

Latrille, P. and Y. Lee, 2012, "Services rules in regional trade agreements: How diverse and how creative as compared to the GATS multilateral rules?" WTO Staff Working Paper ERSD-2012-19.

Limão, N. and A.J. Venables, 2001, "Infrastructure, Geographical Disadvantage, Transport Costs and Trade," World Bank Economic Review, 15: 451-79.

Lui, D. and C. Siziba, 2012, Trade Facilitation Issues in the Political Economy of Regional Integration in Southern Africa, Maastricht, ECPDM and Johannesburg, SAllA.

Lyakurwa, W., McKay, A., Ng'eno, N., Kennes, W., 1997. "Regional integration in Sub-Saharan Africa: a review of experiences and issues," in A. Oyejide, I. Elbadawi and P. Collier (Eds.), Regional Integration and Trade Liberalization in Sub-Saharan Africa. London: Macmillan.

McMillan, M. and K. Harttgen, 2014, "What Is Driving the 'Africa Growth Miracle'?" NBER Working Paper 20077.

Miroudot, S. and B. Shepherd, 2016, "Trade Costs and Global Value Chains in Services," in M. Roy and P. Sauvé (eds.), Research Handbook on Trade in Services, Edward Elgar.

Moïsé, E., and S. Sorescu. 2013. "Trade Facilitation Indicators: The Potential Impact of Trade Facilitation on Developing Countries' Trade," Trade Policy Paper 144. Paris: OECD.

Mold, A. and R. Mukwaya, 2016, "Modelling the economic impact of the tripartite free trade area: Its implications for the economic geography of Southern, Eastern and Northern Africa," Journal of African Trade, 3(1-2): 57-84.

Morris, M. and J. Fessehaie, 2015, "The industrialization challenge for Africa: Towards a commodities based industrialization path," Journal of African Trade, 1(1): 25-36.

Naumann, E. 2014, "The Tripartite FTA: Background and Progress made in Harmonizing Rules of Origin," in TRALAC, Monitoring Regional Integration in Southern Africa. Stellenbosch: TRALAC.

Nicita, A., G. Porto and M. Olarreaga, 2014, "Pro-Poor Trade Policy in Sub-Saharan Africa," Journal of International Economics, 92(2): 252-65.

Njinkeu, D., and O. Hartmann, 2015, Unlocking Trade for Low-Income Countries: Report of the Trade Facilitation Facility, 2009-2015, Washington DC: The World Bank.

Njinkeu, D., J. Wilson and B. Fosso, 2008. "Expanding Trade within Africa: The Impact of Trade Facilitation," Policy Research Working Paper 4790. Washington DC: The World Bank.

Njinkeu, D., F. Doumbouya and E.O. Ogunkonla, 2017, "Impact Analysis of the Tariff Dimension of Fiscal Incentives for Supporting Local Producers in Nigeria," report submitted to GIZ "Strengthening Nigeria's Trade Support Institutions (SNTSI)" programme.

Nordås, H. 2011. "Opening the Markets for Business Services: Industrial Perspective for Developing Countries," Journal of Economic Integration, 26: 306-28.

Nordås, H. 2016, "Services Trade Restrictiveness Index (STRI): The Trade Effect of Regulatory Differences", Trade Policy Papers 189, OECD Publishing, Paris.

Nunn, N. and D. Trefler, 2015, "Domestic Institutions as a Source of Comparative Advantage," in Gopinath et al. (eds.) Handbook of International Economics, vol. 4, North- Holland.

OECD. 2012. The Costs and Challenges of Trade Facilitation Measures. Paris: OECD.

OECD, 2017, International Regulatory Cooperation and Trade: Understanding the Trade Costs of Regulatory Divergence and the Remedies. Paris: OECD.

Oyejide, T. A., B. Ndulu, and D. Greenaway (eds.). 1999. Regional Integration and Trade Liberalization in sub-Saharan Africa. Volume 4. Synthesis and Review. New York: Macmillan.

Oyejide, T. A., E. O. Ogunkola, A. O. Oyeranti, and I. Adeleke, 2013, "Study of the Impact of Nigeria's Rice Import Restrictions," report submitted to DfID-Nigeria, 22 August. 
Persson, M. 2013. "Trade facilitation and the extensive margin," Journal of International Trade \& Economic Development, 22(5): 658-93.

Persson, M. and F. Wilhelmsson, 2013, "EU trade preferences and export diversification," IFN Working Paper, No. 991.

Pesce, O., S. Karingi and I. Gebretensaye, 2015, "Trade growth prospects: An African perspective," in B. Hoekman (ed.), The Global Trade Slowdown: A New Normal? London: CEPR.

Portugal-Perez, A. and J. Wilson, 2012. "Export Performance and Trade Facilitation Reform: Hard and Soft Infrastructure," World Development, 40(7): 1295-1307.

Rodriguez, F. and D. Rodrik. 2001. "Trade Policy and Economic Growth: A Skeptic's Guide to the Cross-National Evidence." In NBER Macroeconomics Annual, edited by Ben S. Bernanke and Kenneth Rogoff. Cambridge, MA: MIT Press.

Rodrik, D. 1998. "Trade Policy and Economic Performance in Sub-Saharan Africa," NBER Working Paper 6562.

Rodrik D., 2008. "The Real Exchange Rate and Economic Growth", Brookings Papers on Economic Activities, No. 2: 365-412.

Rajan, R. and L. Zingales, 1998, "Financial Dependence and Growth," American Economic Review, 88 (3): 559-86.

Saslavsky, D., and B. Shepherd. 2014. "Facilitating International Production Networks: The Role of Trade Logistics," Journal of International Trade \& Economic Development 23(7): 979-99.

Spence, M. and S. Karingi. 2011. "Impact of Trade Facilitation Mechanisms on Export Competitiveness in Africa," ATPC Working Paper 85.

Storeygard, A. 2016. "Farther on down the Road: Transport Costs, Trade and Urban Growth in SubSaharan Africa," Review of Economic Studies 83: 1263-95.

Swinnen, J. and E. Janssen, 2016, "Political Economy of Agricultural and (Regional) Trade Policies and Value Chain Performances in Sub-Saharan Africa," in Brenton and Hoffman.

van Tongeren, F., J. Beghin, and S. Marette, 2009, A Cost-Benefit Framework for the Assessment of Non-Tariff Measures in Agro-Food Trade, OECD Food, Agriculture and Fisheries Working Papers, No. 21, OECD Publishing.

van Tongeren, F., V. Bastien and M. van Lampe, 2015, "International Regulatory Co-operation, a trade-facilitating mechanism," at: http://e15initiative.org/wp-content/uploads/2015/09/E15Regulatory-Coherence-van-Tongeren-Bastien-von-Lampe-Final.pdf.

von Uexkull, E., D. Njinkeu, J-C Maur, A. Coste and L. Shui, 2014, ECOWAS Economic Partnership Agreement With the EU and Nigeria Trade and Development. Washington DC: World Bank.

UNECA. 2013. Making the Most of Africa's Commodities: Industrializing for Growth, Jobs and Economic Transformation. Addis Ababa: Economic Commission for Africa.

World Bank and East African Community Secretariat. 2016. EAC Common Market Scorecard 2016: Tracking EAC Compliance in Movement of Capital Services and Goods. Arusha and Washington DC: EAC Secretariat and World Bank Group.

WTO. 2015. World Trade Report 2015: Speeding up trade: benefits and challenges of implementing the WTO Trade Facilitation Agreement. Geneva: WTO.

WTO. 2016. World Trade Statistical Review. Geneva: WTO.

WTO, ITC and UNCTAD, 2017, World Tariff Profiles. Geneva: WTO. 


\section{Annex: Assessing the impact of services trade restrictions ${ }^{24}$}

Beverelli et al. (2017) follow the approach proposed by Rajan and Zingales (1998) and assume that the effect of services trade policy on downstream industries is a positive function of the intensity with which services are used as intermediate inputs by the latter. They use the World Bank's services trade restrictiveness indices (STRIS) to estimate the following model:

$$
y_{i j}=\alpha+\beta \operatorname{CSTRI}_{i j}+\mu\left(\operatorname{CSTRI}_{i j} \times I C_{i}\right)+\gamma x_{i j}+\delta_{i}+\delta_{j}+\epsilon_{i j}
$$

where $y_{i j}$ is the natural logarithm of productivity in downstream sector $j$ in country $i, I C_{i}$ is a measure of economic governance (quality of the investment climate) in country $i, x_{i j}$ is a control variable (the average level of tariff protection for non-services inputs used by downstream manufacturing sector $j$ ) and $\operatorname{CSTRI}_{i j}$ is a measure of the effective restrictiveness of services trade policy confronted by downstream sector $j$ in country $i$. The latter is constructed by calculating $\sum_{s} S T R I_{i s} \times w_{i j s}$ where $S T R I_{i s}$ is the level of services trade restrictiveness for country $i$ and service sector $s$ going from 0 as complete openness to 100 as full restrictiveness and $w_{i j s}$ are a set of weights that reflect the use of service $s$ by manufacturing sector $j$ in country $i$. The input-output coefficients for the United States is used to calculate these weights. ${ }^{25}$ The same approach is used to weight the effect of import tariffs on intermediate goods used in downstream manufacturing sectors.

The estimated coefficient on $\operatorname{CSTRI}_{i j}(\beta)$ and the interaction effect $(\mu)$ provide a qualitative assessment of the impact of higher services trade policy restrictions on downstream industries, assuming at least some level of demand for services is observed. Beverelli et al. (2016) find that higher STRIs are associated with lower productivity performance in downstream sectors, but that this effect if highly dependent on the quality of governance, as measured by standard indicators compiled by the World Bank such as the rule of law, regulatory quality and control of corruption. The marginal effect of reducing barriers to services trade on downstream productivity accounting for cross-country heterogeneity in economic governance $-\frac{\partial y}{\partial C S T R I}=\beta+\mu \times I C_{i}$ - increases with the quality of governance $(\mu<0)$ and it is positive and statistically significant at the 0.05 percent level for $65 \%$ of their sample observations (33 out of 57 countries). This conditionality result is robust to a variety of alternative approaches and instruments to account for measurement and endogeneity issues. ${ }^{26}$

To quantitatively assess how much the downstream effect of services trade policy is influenced by economic governance quality in a country, the estimates of the interaction model can be used to calculate the productivity changes associated with complete removal of the restrictions to services. In the STRI database a fully unrestricted trade policy regime corresponds to an STRI with a value of 0 . Therefore, the policy change associated with a country removing all existing barriers to trade through commercial presence in services sector $s$ is given by $0-S T R I_{i s}$. The variation in the independent variable CSTRI reflecting full liberalization of trade across services sectors ${ }^{27}$ is then given by:

$$
\Delta C S T R I_{i j}=\sum_{s}\left(0-S T R I_{i s}\right) \times w_{i j s}
$$

\footnotetext{
${ }^{24}$ This Annex draws on Fiorini and Hoekman (2017).

${ }^{25}$ Input output weights are given by shares of intermediate consumption.

${ }^{26}$ Robustness checks in Beverelli et al. (2017) include instrumentation, random assignment of the policy component of CSTRI and alternative input-output weights and productivity measures.

${ }^{27}$ The four services sectors are finance, transportation, communications and business services. See Borchert, Gootiiz and Mattoo (2014) for details on the sectoral classification used in the STRI database.
} 
The associated change in productivity (expressed in levels) implied by the estimated coefficients ( $\beta$ and $\mu$ ) can then be computed as follows:

$$
\% \Delta Y_{i j}=100 \times\left(\beta+\mu \times I C_{i}\right) \times \Delta C S T R I_{i j}
$$

This expression is country-sector specific. The productivity effect of services trade policy is a function of services input intensities at the downstream sector level and two country-level variables. The first is the policy change required to reach complete openness; the second is the quality of economic governance. This methodology permits counterfactual quantification of the effects of trade policy for country $i$ assuming the level of economic governance of a benchmark country, $b$. 